\title{
Extraction of Lipase from Burkholderia cepacia by PEG/Phosphate ATPS and Its Biochemical Characterization
}

\author{
Giovana da Silva Padilha ${ }^{1}$, José Carlos Curvelo Santana ${ }^{2}$, Ranulfo Monte Alegre ${ }^{3}$ and Elias \\ Basile Tambourgi ${ }^{*}$ \\ ${ }^{I}$ Departamento de Engenharia de Sistemas Químicos; Faculdade de Engenharia Química; Universidade Estadual \\ de Campinas; Av. Albert Einstein 500, CP: 6066; 13083-970; Campinas - SP - Brasil. ${ }^{2}$ Programa de Pós- \\ Graduação em Engenharia Industrial; Universidade Nove de Julho; São Paulo - SP - Brasil. ${ }^{3}$ Faculdade de \\ Engenharia de Alimentos; Universidade Estadual de Campinas; Campinas - SP - Brasil
}

\begin{abstract}
This work aimed to study the partitioning of a lipase produced by Burkholderia cepacia in PEG/Phosphate aqueous two phase system (ATPS) and its characterization. Lipase was produced by B. cepacia strains in a fermenter. Enzyme partitioning occurred at pH 6.0 and 8.0, using PEG 1500 and 6000 on two tie lines. Metal ions, pH and temperature effects on enzyme activity were evaluated. Five milliliter of $7.5 \%$ olive oil emulsion with $2.5 \%$ gumarabic in 0.1M sodium phosphate buffer at $\mathrm{pH} 8.0$ and $37^{\circ} \mathrm{C}$ were used for the activity determinations. Results showed that crude stratum from B. cepacia was partitioned by PEG1500/phosphate ATPS at pH 6.0 or 8.0 for, which the partitioning coefficients were 108-and 209-folds. Lipase presented optimal activity conditions at $37^{\circ} \mathrm{C}$ and $\mathrm{pH}$ 8.0; it showed $\mathrm{pH}$-stability for $4 \mathrm{~h}$ of incubation at different $\mathrm{pH}$ values at $37^{\circ} \mathrm{C}$. Metal ions such as $\mathrm{Mn}^{2+}$, $\mathrm{Co}^{2+}, \mathrm{I}$ and $\mathrm{Ca}^{2+}$ sustained enzymatic activities; however, it was inhibited by the presence of $\mathrm{Fe}^{2+}, \mathrm{Hg}^{2+}$ and $\mathrm{Al}^{3+}$. $K_{m}$ and $V_{\max }$ values were $0.258 \mathrm{U} / \mathrm{mg}$ and $43.90 \mathrm{~g} / \mathrm{L}$, respectively. A molecular weight of $33 \mathrm{kDa}$ and an isoelectric point at pH 5.0 were determined by SDS-PAGE and IFS electrophoresis, respectively.
\end{abstract}

Key words: lipase, Burkholderia cepacia, aqueous two phase system, partitioning, characterization

\section{INTRODUCTION}

Lipases (triglycerol acyl-hydrolases E.C. 3.1.1.3) are enzymes that catalyze the hydrolysis of water insoluble triglycerides to $\mathrm{di}$ and monoacylglycerides, free fatty and glycerol. Lipases have been utilized for the esterification, transesterification and resolutions of chiral substrates. Usually, the highest catalytic activity of lipases occurs in water/lipid interface, and they are activated in the presence of emulsified esters. This definition disregards the enzymes which perform their hydrolytic functions under water-soluble substrates (esterases) or which hydrolyze other lipids as acylhydrolases, cholesterol esterase, thiolesterases, among others (Borgström and Brockman 1984; Balcão 1996; Paiva et al. 2000).

Hydrolytic enzymes constitute the main class of enzymes employed in the industry. Lipases catalyze lipid hydrolysis, which make them attractive for the applications in diversified industrial sectors. Lipases usage as additives in detergents still represents the main industrial application of these enzymes (Kirk et al. 2002; Ranganathan et al. 2008). The hydrolytic capability of lipases has been explored in paper and cellulose industry to remove hydrophobic material from the wood, undesired to paper

*Author for correspondence: eliastam@feq.unicamp.br 
manufacture (Jaerger and Reetz 1998). This capability is also employed to treat the effluents that may be used to remove the oil from the residual waters of factories, restaurants, residences, or even of oil refineries that pollute soil and water, as well as to remove fat deposits formed in tubing systems for hot water, beverages or liquid food. Lipases have also been responsible for the development of aromas in biodiesel, cheese and derivatives, alcoholic drinks, chocolates and desserts, by the selective hydrolysis of triacylglycerols and release of fatty acids, which act as flavorings or as their precursors (Borgström and Brockman 1984; Cammarota et al. 2001; Pandey et al. 1999; Pencreac'h and Barrati 1996; Ranganathan et al. 2008; Sharma et al. 2002; Singh and Banerjee 2007).

Lipases can be found in different organisms, including animals, plants, fungi and bacteria. From Claude Bernard discovery, lipases were initially obtained from the animal pancreas, but owing to the difficulty of obtaining these sources, there was an increase in the interest for microbial lipases which, due to the easy production and greater source of microorganisms capable of synthesizing them, are the most commonly used. The main procedure of producing the lipases by fermentative processes demonstrates control facility and productive capability, as well as reduced obtainment cost (Borgström and Brockman 1984; Hasan et al. 2006). Among the microorganisms that produce lipase, Rhizopus, Aspergillus and Mucor fungi, Pseudomonas bacteria and Candida yeasts are outstanding. Fast cellular growth is one of the advantages of bacterial sources as enzyme producers, besides being considered of high biotechnological potential due to its stability at high temperatures and organic solvents. Depending on the source, lipases may have molecular weight ranging from 20 to $75 \mathrm{kDa}$, optimal $\mathrm{pH}$ activity between 6.0 and 8.0 and at temperatures between 30 and $40^{\circ} \mathrm{C}$ (Borgström and Brockman 1984; Beisson et al. 2000; Kordel et al. 1991).

Approximately $20 \%$ of biotransformation derives from the reactions with lipases; this is why they comprise one of the most important groups of biotechnological value. Therefore, lipase biochemical characterization is extremely important to know and establish its application conditions. Literature describes the studies in which this enzyme performance ranges vary according to the utilized microorganism. In this study, Burkholderia cepacia lipase partitioning and characterization was carried out so as to know its performance.

\section{MATERIALS}

\section{Microorganism}

ABurkholderia cepacia strain was utilized, which was obtained from André Tosello Foundation and kept in test tubes at $4^{\circ} \mathrm{C}$ in nutrient agar.

\section{Equipment}

Sterilization of growth and production medium and glass wares was performed at $121^{\circ} \mathrm{C}$ for 15 minutes. The shaker utilized for lipolytic analysis and enzymatic characterization was TE-421 from Tecnal, and BIOFLO III reactor from New Brunswick Scientific was used in the production of the lipases.

\section{Reagents}

Acetone, ethyl alcohol, monobasic sodium phosphate, dibasic sodium phosphate, sodium hydroxide, and other salts, both with PA degree, were used to determine the characterization and fermentation stage, were obtained from Synth (Diadema-SP); Arabic-gum, agar-agar, yeast extract and peptone were obtained from Oxoid (England, London); Liza soybean oil and Gallo olive oil were bought from a retail store locally. Polyethylene glycol (PEG) with molecular weight of 6000 was obtained from Sigma Chemical (St. Louis, USA), as well as a mixture of salts for stock solution: monobasic potassium phosphate and dibasic potassium phosphate, both from Synth (Diadema-SP). Commercial lipase used in the electrophoresis was obtained from Sigma Chemical (St. Louis, USA).

\section{METHODS}

\section{Inoculums preparation and fermentative system}

Inoculums was transferred from test tubes to Erlenmeyer flasks of $125 \mathrm{~mL}$, containing yeast extract $(3 \mathrm{~g} / \mathrm{L})$, peptone $(3 \mathrm{~g} / \mathrm{L}), \mathrm{KH}_{2} \mathrm{PO}_{4}(4 \mathrm{~g} / \mathrm{L})$, $\mathrm{MgSO}_{4}(0.2 \mathrm{~g} / \mathrm{L})$ and $3 \%$ of soybean oil. Microorganism adaptation was performed during $48 \mathrm{~h}$ at $30^{\circ} \mathrm{C}$ and $150 \mathrm{rpm}$. After this, inoculums was transferred to a bioreactor Bioflo III (with 
useful volume of $5000 \mathrm{~mL}$, containing a medium of $3000 \mathrm{~mL}$ ). Air was provided by the compressor, sterilized by glass wool filter and with flow controlled by rotameters. The culture medium had the same concentrations as those of the reagents prepared for the inoculums, but with $6 \%(\mathrm{v} / \mathrm{v})$ of soybean oil to induce lipase production. Fermentation was performed at $30^{\circ} \mathrm{C}, \mathrm{pH} 7.0,1.5$ vvm of aeration and stirring of $150 \mathrm{rpm}$ for $96 \mathrm{~h}$ (Macedo et al. 1997; Padilha et al. 2009a and 2009b; Pastore et al. 2003).

\section{Making of enzymatic extract}

During intervals of $24 \mathrm{~h}, 15 \mathrm{~mL}$ of the fermented medium were collected and centrifuged for $10 \mathrm{~min}$ at 2016g. Supernatants were used as crude enzymatic extract (Macedo et al. 1997; Padilha et al. 2009a and 2009b; Pastore et al. 2003).

\section{Determination of the lipolytic activity}

Lipolytic activity was determined according to the methodology by Kamimura et al. (1999), Macedo (1997) and Pastore et al. (2003). Lipase assay was performed with olive oil emulsion, which was prepared by mixing $25 \mathrm{~mL}$ of olive oil and $75 \mathrm{~mL}$ Arabic-gum 7\% solution in a homogenizer for 4 min. The reaction mixture containing $5.0 \mathrm{~mL}$ of olive oil emulsion, $2.0 \mathrm{~mL}$ of $100 \mathrm{mM}$ phosphate buffer $(\mathrm{pH} 8.0)$ and $1.0 \mathrm{~mL}$ of the culture was incubated at $37^{\circ} \mathrm{C}$ for $30 \mathrm{~min}$ with orbital shaking at $150 \mathrm{rpm}$. The reaction was immediately stopped after incubation by the addition of $15 \mathrm{~mL}$ acetone:ethanol mixture $(1: 1, \mathrm{v} / \mathrm{v})$, and the liberated free fatty acids were titrated with $50 \mathrm{mM}$ $\mathrm{NaOH}$. One unit (U) of lipase activity was defined as the amount which liberated $1 \mu \mathrm{mol}$ of fatty acid per min.

\section{Enzyme characterization}

The optimum $\mathrm{pH}$ of the enzyme was determined by measuring its activity for $30 \mathrm{~min}$ in the $\mathrm{pH}$ range of $3.0-11.0$ at $37^{\circ} \mathrm{C} \pm 2^{\circ} \mathrm{C}$, using $5.0 \mathrm{~mL}$ of olive oil emulsion at $100 \mathrm{mM}$ : citrate buffer $(\mathrm{pH}$ from 3.0 to 5.0); phosphate buffer ( $\mathrm{pH}$ from 6.0 to 8.0); carbonate-bicarbonate buffer ( $\mathrm{pHs}$ from 9.0 to 11.0). The optimum temperature was obtained measuring its activity, for $30 \mathrm{~min}$ at temperatures between 25 and $50^{\circ} \mathrm{C} \pm 2^{\circ} \mathrm{C}$, using the olive oil emulsion acetate, at $\mathrm{pH}$ 8.0. The activation energy was determined by Arrhenius method. Initial rates of hydrolysis of the olive oil were determined at various substrate concentrations $(0.5-50 \%, \mathrm{p} / \mathrm{p})$ at $\mathrm{pH} 8.0$ and $37^{\circ} \mathrm{C}$. The kinetic constants $K_{m}$ and
$V_{\max }$ were estimated by Lineweaver-Burk method. Ions effect also determined to observe the activation and inhibition of ions such as $\mathrm{Co}^{2+}$, $\mathrm{Hg}^{2+}, \mathrm{Cu}^{2+}, \mathrm{Ba}^{2+}, \mathrm{Fe}^{2+}$ and others (Aguilar et al. 2000; Biazus et al. 2009; Padilha et al. 2009a; Toledo et al. 2007; Wanderley et al. 2004). Proteins content was measured by Bradford method (Bradford, 1976).

\section{Binodal curves and tie lines}

Solutions of PEG 6000 and 1500 (50\%,w/w) and phosphate buffer $(20 \%, \mathrm{w} / \mathrm{w})$ of known concentrations were prepared at $\mathrm{pH} 6.0$ and 8.0. A given volume of PEG solution was added to the buffer solution until became turbid. The phase compositions were determined to obtain the binodal curve and tie-line length. PEG 6000 (or PEG 1500) and phosphate buffer solutions were mixed together until equal volumes of the phases (Albertsson 1986; Biazus et al. 2006 and 2007; Diamond and Hsu 1992; Ferreira et al. 2009 and 2011; Ferreira et al. 2007; Fileti et al. 2009 and 2010; Padilha et al. 2011).

\section{Purification stage}

In this study, PEG and phosphate salt at $\mathrm{pH} 6.0$ were used for ATPS with two tie lines. Iit was put into graduated centrifuge tubes, with a total weight of $8 \mathrm{~g}$, by weighing the appropriate amounts of PEG 6000 and 1500 at 50\% and phosphate salt at $20 \%$. A $0.2 \mathrm{~mL}$ from crude stratum was added into the tubes, stirred in vortex and, after reaching the diffusive balance (between 12 and $24 \mathrm{~h}$ ), $1.0 \mathrm{~mL}$ of sample for each stage was collected (Albertsson 1986; Biazus et al. 2006 and 2007; Diamond and Hsu 1992; Ferreira et al. 2011; Fileti et al. 2009 and 2010; Ferreira et al. 2009). Determination of total protein concentration in inferior and superior stages was measured by the method of Bradford (1976). Enzymatic activity was determined by the methodology described by Macedo et al. (1997) and Pastore et al. (2003). The partition coefficient was obtained with equation 1 :

$$
K=\frac{C_{\text {top }}}{C_{\text {bottom }}}
$$

\section{SDS-PAGE Electrophoresis and isoelectric focusing (IEF)}

Before and after the purification in aqueous twophase system (ATPS) PEG/phosphate salt, lipase samples were analyzed by SDS-PAGE electrophoresis, performed with Mini Protean III 
(BioRad, USA) and utilizing polyacrylamide gel according to protocol introduced by Laemmli (1970), in a concentration of 7.5\%. Samples were treated with the buffers containing SDS in denaturant and reducing conditions (with the presence of $\beta$-mercaptoethanol). Denaturation of sample proteins was performed by heating at $100{ }^{\circ} \mathrm{C}$ for $10 \mathrm{~min}$. Aliquots of $15 \mu \mathrm{L}$ of each sample and $5 \mu \mathrm{L}$ of low molecular weight indicator were applied on the gels of $7.5 \%$. These gels were submitted to a voltage of $180 \mathrm{~V}$, in a vertical bowl. Low molecular weight indicator contained the following proteins: phosphorylase $b$ (97 kDa), albumin (66 kDa), ovalbumin (45 kDa), carbonic anhydrase (30 kDa), trypsin inhibitor (20.1 kDa), $\alpha$-lactalbumin (14.4 kDa), and both kits from GE Healthcare (USA). For the electrophoresis of isoelectric focusing (IEF), the equipment PhastSystem was utilized (Pharmacia,
Sweden) at $410 \mathrm{Vh}$ and acrylamide gradient gels in $5 \%$ concentration ranging between $\mathrm{pH} 3.0$ and 9.0 from GE Healthcare (USA), in accordance with the method described by the manufacturer. In both the techniques, gel coloration was performed with silver nitrate (Biazus et al. 2007 and 2009; Fileti et al. 2009; Morrissey 1981).

\section{RESULTS AND DISCUSSION}

\section{Binodal curves and tie lines}

Figures 1 and 2 show the $\mathrm{pH}$ effect on phase diagrams of PEG/phosphate ATPS. There was an influence of $\mathrm{pH}$, which dislocated the binodal curves of these ATPS. For the reduced $\mathrm{pH}$, there was a large need of PEG concentration for twophase formation (Albertsson 1986; Ferreira et al. 2007; Silva and Franco 2000).

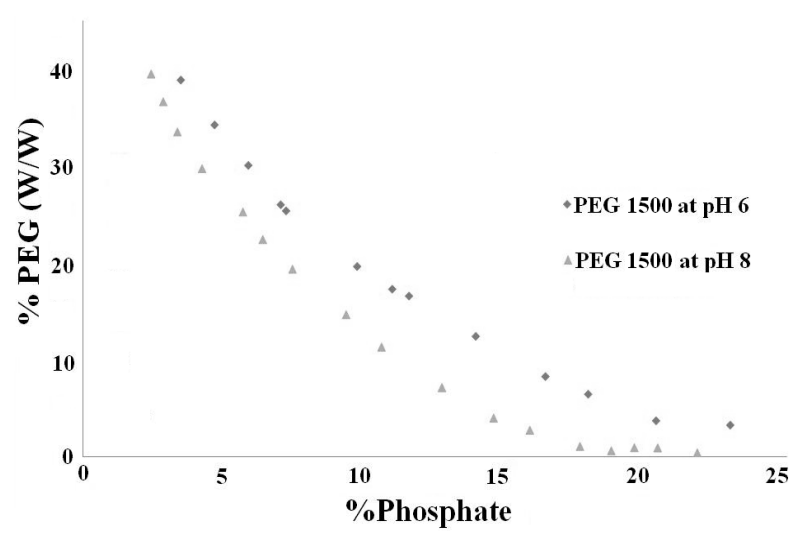

Figure 1 - Phase diagrams of PEG 1500/Phosphate ATPS on $\mathrm{pH}$ effect, at $25^{\circ} \mathrm{C}$.

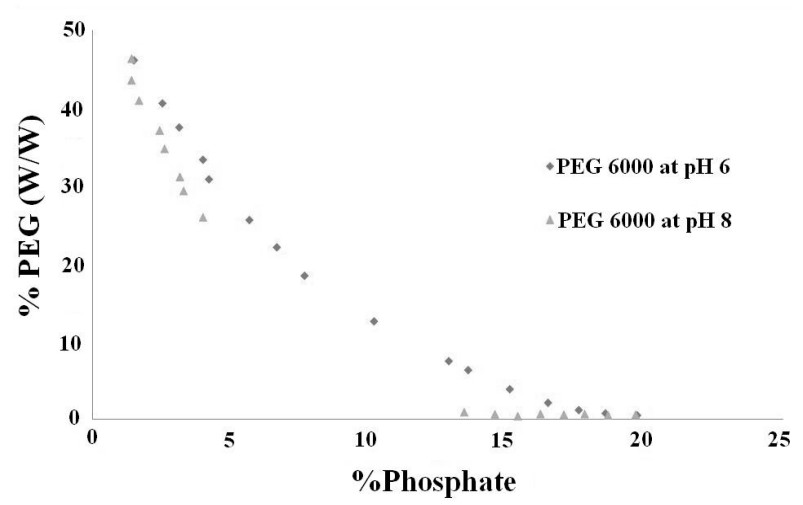

Figure 2 - Phase diagrams of PEG 6000/Phosphate ATPS on pH effect, at $25^{\circ} \mathrm{C}$. 
Figures 3 and 4 show the effect of the PEG molar weight on phase diagrams of PEG /phosphate ATPS. The lower molar mass needed of a large PEG concentration for two-phase formation (Albertsson, 1986; Silva and Franco, 2000). However, according to Diamond and Hsu (1992), the $\mathrm{pH}$ and PEG molar weight effects on PEG-salt systems was not fully elucidated.

Tables 1 and 2 show the tie-line compositions for PEG 1500 and 6000/ phosphate at pH 6.0 and 8.0, respectively. There were significant differences among the composition systems.

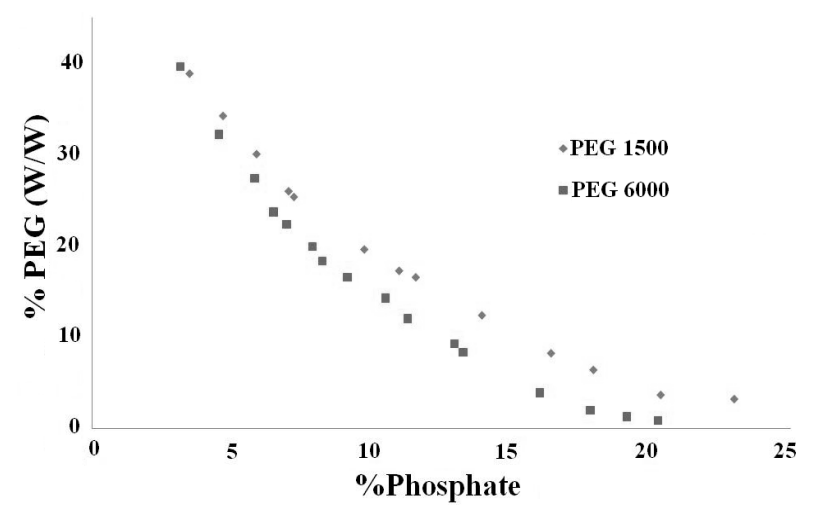

Figure 3 - Phase diagrams of PEG/Phosphate ATPS at pH 6 and $25^{\circ} \mathrm{C}$.

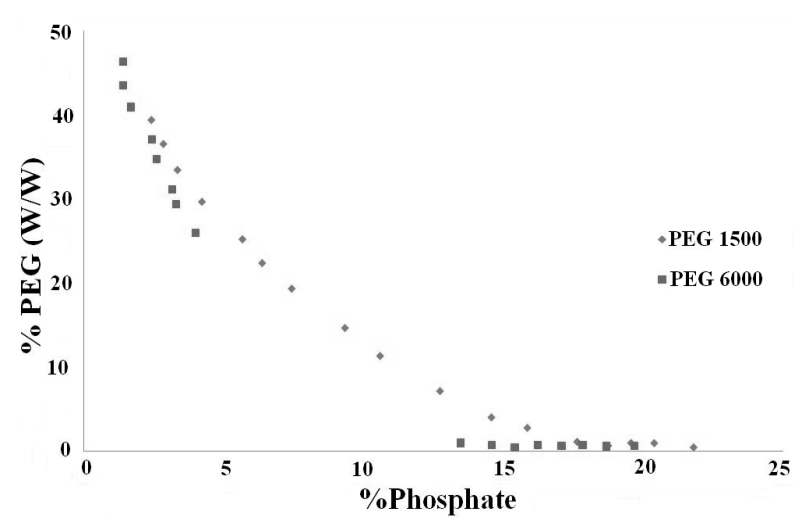

Figure 4 - Phase diagrams of PEG/Phosphate ATPS at pH 8 and $25^{\circ} \mathrm{C}$.

Table 1 - Phase compositions of PEG1500/Phosphate ATPS.

\begin{tabular}{|c|c|c|c|c|c|c|c|c|c|c|}
\hline \multirow[t]{2}{*}{$\mathrm{pH}$} & \multirow{2}{*}{$\begin{array}{l}\text { Tie } \\
\text { Line }\end{array}$} & \multicolumn{3}{|c|}{$\begin{array}{l}\text { Total System Composition } \\
(\mathrm{w} / \mathrm{w})\end{array}$} & \multicolumn{3}{|c|}{$\begin{array}{l}\text { Top Phase Composition } \\
\text { (w/w) }\end{array}$} & \multicolumn{3}{|c|}{$\begin{array}{l}\text { Bottom Phase Composition } \\
\text { (w/w) }\end{array}$} \\
\hline & & PEG & Salt & Water & PEG & Salt & Water & PEG & Salt & Water \\
\hline \multirow{2}{*}{6} & 1 & 17.8 & 12.9 & 69.3 & 31.0 & 5.6 & 63.4 & 5.0 & 19.5 & 75.5 \\
\hline & 2 & 14.8 & 12.6 & 72.6 & 21.0 & 9.3 & 69.7 & 9.0 & 16.0 & 75.0 \\
\hline \multirow{2}{*}{8} & 1 & 17.9 & 12.0 & 70.1 & 35.0 & 3.2 & 64.8 & 0.7 & 20.5 & 78.8 \\
\hline & 2 & 16.8 & 11.0 & 72.2 & 33.0 & 3.6 & 63.4 & 0.6 & 18.7 & 80.7 \\
\hline
\end{tabular}

Table 2 - Phase compositions of PEG 6000/Phosphate ATPS.

\begin{tabular}{|c|c|c|c|c|c|c|c|c|c|c|}
\hline \multirow{2}{*}{$\mathrm{pH}$} & \multirow{2}{*}{$\begin{array}{l}\text { Tie } \\
\text { Line }\end{array}$} & \multicolumn{3}{|c|}{$\begin{array}{l}\text { Total System Composition } \\
(\mathrm{w} / \mathrm{w})\end{array}$} & \multicolumn{3}{|c|}{$\begin{array}{l}\text { Top Phase Composition } \\
\text { (w/w) }\end{array}$} & \multicolumn{3}{|c|}{$\begin{array}{l}\text { Bottom Phase Composition } \\
(\mathrm{w} / \mathrm{w})\end{array}$} \\
\hline & & PEG & Salt & Water & PEG & Salt & Water & PEG & Salt & Water \\
\hline \multirow{2}{*}{6} & 1 & 19.0 & 12.3 & 68.7 & 36.0 & 3.4 & 60.6 & 1.7 & 21.0 & 77.3 \\
\hline & 2 & 9.7 & 12.3 & 78.0 & 17.0 & 8.5 & 74.5 & 2.2 & 16.0 & 81.8 \\
\hline \multirow{2}{*}{8} & 1 & 23.7 & 10.5 & 65.8 & 43.6 & 1.4 & 55.0 & 3.0 & 20.0 & 77.0 \\
\hline & 2 & 18.3 & 9.9 & 73.5 & 35.0 & 2.8 & 62.2 & 0.5 & 18.0 & 81.5 \\
\hline
\end{tabular}




\section{Lipase partitioning by PEG/Phosphate ATPS} Tables 3 and 4 show the assays, with the varying of PEG molar weight $\mathrm{pH}$ and tie line (TL). The tables, also showed the activity, protein and specific activity (SA) measured after the equilibrium of phases in the bottom and top phases from PEG1500 and 6000/Phosphate ATPS. These results were used for the calculation of partitioning coefficient (K) of lipase from B. cepacia, as shown in Table 5. The best results to lipase purification were at PEG 1500/phosphate ATPS for, the $\mathrm{pH} 6.0$ or 8.0 and the tie lines 2 (high PEG content), which the partitioning coefficient of the specific activity were amongst 108 and 209 times, respectively.

Lipase purification method applied in this work was very efficiently. These results were very significant, principally, while compared to methods showed by other authors.

Saxena et al. (2003) purified the lipases from $C$. Viscosum in the first process by AOT/iso-octane reversed micelles with an activity recovery of $91 \%$ and purification factor of 4.3 ; in a second purification, Amberlite CG and Shefadex chromatography was used, where an activity recovery of $2.8 \%$ and a purification factor of 23 was found; and in a third purification, a lipase from B. Streamthermofilus by CM-Sepharose and DEAE-Sepharose chromatography was purified, where an activity recovery of $62.2 \%$ and a purification factor of 11.6 were found.

Table 3 - Biomolecules partitioning on top phase by PEG/Phosphate ATPS.

\begin{tabular}{ccccccc}
\hline Assay & PEG & pH & TL & Activity (U/mL) & Protein (mg/L) & SA (U/mg) \\
\hline 1 & 6000 & 8 & 2 & 6.01 & 122.33 & 49.15 \\
2 & 6000 & 8 & 1 & 2.40 & 121.22 & 19.84 \\
3 & 6000 & 6 & 2 & 18.72 & 222.10 & 84.29 \\
4 & 6000 & 6 & 1 & 9.44 & 181.89 & 51.92 \\
5 & 1500 & 8 & 2 & 9.52 & 73.77 & 129.03 \\
6 & 1500 & 8 & 1 & 3.34 & 35.80 & 93.29 \\
7 & 1500 & 6 & 2 & 1.44 & 214.87 & 6.68 \\
8 & 1500 & 6 & 1 & 17.66 & 99.08 & 178.24 \\
\hline
\end{tabular}

$\mathrm{TL}=$ Tie Line; $\mathrm{SA}=$ specific activity

Table 4 - Biomolecules partitioning on bottom phase by PEG/Phosphate ATPS.

\begin{tabular}{ccccccc}
\hline Assay & PEG & pH & TL & Activity (U/mL) & Proteins (mg/L) & SA (U/mg) \\
\hline 1 & 6000 & 8 & 2 & 7.16 & 1031.89 & 6.94 \\
2 & 6000 & 8 & 1 & 11.98 & 1411.56 & 8.49 \\
3 & 6000 & 6 & 2 & 20.12 & 1415.23 & 14.22 \\
4 & 6000 & 6 & 1 & 24.26 & 2718.23 & 8.92 \\
5 & 1500 & 8 & 2 & 2.56 & 2134.34 & 1.20 \\
6 & 1500 & 8 & 1 & 3.84 & 206.64 & 18.59 \\
7 & 1500 & 6 & 2 & 0.02 & 625.25 & 0.03 \\
8 & 1500 & 6 & 1 & 14.98 & 337.92 & 44.33 \\
\hline
\end{tabular}

$\mathrm{TL}=$ Tie Line; $\mathrm{SA}=$ specific activity

Table 5 - Lipase partitioning coefficients by PEG1500 and 6000/Phosphate ATPS.

\begin{tabular}{ccccc}
\hline Assay & PEG & pH & TL & Partitioning coefficient \\
\hline 1 & 6000 & 8 & 2 & 7.079 \\
2 & 6000 & 8 & 1 & 2.337 \\
3 & 6000 & 6 & 2 & 5.928 \\
4 & 6000 & 6 & 1 & 5.818 \\
$\mathbf{5}$ & $\mathbf{1 5 0 0}$ & $\mathbf{8}$ & $\mathbf{2}$ & $\mathbf{1 0 7 . 8}$ \\
6 & 1500 & 8 & 1 & 5.019 \\
$\mathbf{7}$ & $\mathbf{1 5 0 0}$ & $\mathbf{6}$ & $\mathbf{2}$ & $\mathbf{2 0 9 . 0}$ \\
8 & 1500 & 6 & 1 & 4.021
\end{tabular}


A lipase $P$. aeruginosa was purified by acetone precipitation and Q-sepharose and Q-sephacril S200 chromatographic steps, and after full purification a purification factor of 21.5-fold was found (Singh and Banerjee 2007). The procedure included phenyl-toyopearl fractionation, DEAESepharose chromatography, and Saphadex300HR chromatography was done to the purification of lipases from $P$. fluorecens HU380. The enzyme was purified 24.3-fold (Kojima and Shimizu 2003). Makhzoum et al (1996) purified a lipases from $P$. fluorecens $2 \mathrm{D}$ by hydrophobic interaction chromatography and a purification factor of 25fold was found.

Lipases from Rizopus $s p$. were purified by the chromatography using the SEPHADEX resin and a purification factor of 5-times was found by Pastore et al. (2003). Bradoo et al. (1999) purified the lipases from B. stearothermophilus SB-1 by PEG/phosphate aqueous two-phase systems (ATPS) and a purification factor of 15.27 fold was found.

\section{Temperature effects on lipase activity}

Enzyme's catalytic activity is very dependent on the temperature; however, as temperature increases, two effects occur: reaction rate increases and decreases enzyme stability due to thermal disablement; thus, temperature is one of the critical agents on enzymatic activities. In this study, assays from 25 to $50^{\circ} \mathrm{C}$ were performed to determine the optimal performance temperature of lipase enzyme. In Figure 5, lipolytic activity results for these conditions are presented. Based on the results, optimal enzyme temperature was $37^{\circ} \mathrm{C}$, at which $100 \%$ of relative activity was observed, presenting an activity of $1.85 \mathrm{U} / \mathrm{mL}$ and specific activity of $29.30 \mathrm{U} / \mathrm{mg}$. The largest variation found for the values of activity was $17 \%$ (between 20 and $37^{\circ} \mathrm{C}$ ).

Some enzymes can lose their activity with small variations in the temperature, since the change in conformation causes lose in its active site specificity to react with the substrate (Biazus et al. 2009; Curvelo Santana et al. 2010). The optimum temperature for the reaction of lipase from $B$. cepacia found in this study was the same found by Pencreac'h and Barrati (1996). Similar values $\left(40^{\circ} \mathrm{C}\right)$ were found by Makhzoum et al. (1996) for P. fluerescens lipase, and by Pastore et al. (2003), utilizing Rhizopus sp lipases. However, Kojima and Shimizu (2003) characterized P. fluorecens HU380 lipases and obtained $45^{\circ} \mathrm{C}$ as the optimal temperature whereas Nawani et al. (2006) have found an optimal temperature ranging from 60$65^{\circ} \mathrm{C}$ for the immobilized lipases and $60^{\circ} \mathrm{C}$ for free lipases of Bacillus sp.

Activation energy of olive oil hydrolysis by the lipases was obtained by linear regression of natural logarithm of the reaction velocity ( $\mathrm{mol} / \mathrm{min} . \mathrm{g}$ of enzyme) versus temperature inverse (K), according to Arrhenius equation (Aguilar et al. 2000; Biazus et al. 2009; Toledo et al. 2007) as shown in Figure 6. Considering that the ideal gases constant value was equal to $8.31451 \mathrm{~J} / \mathrm{mol} . \mathrm{K}$, the activation energy value of this reaction was considered close to $75.8 \mathrm{~kJ} / \mathrm{mol}$. There are no reports in literature on this aspect.

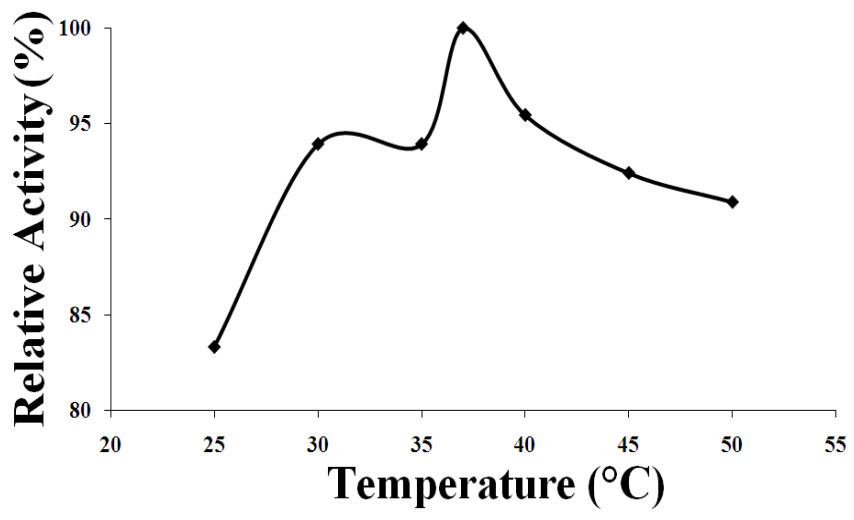

Figure 5 - Temperature effect on lipolytic activity of crude stratum of B. cepacia. 


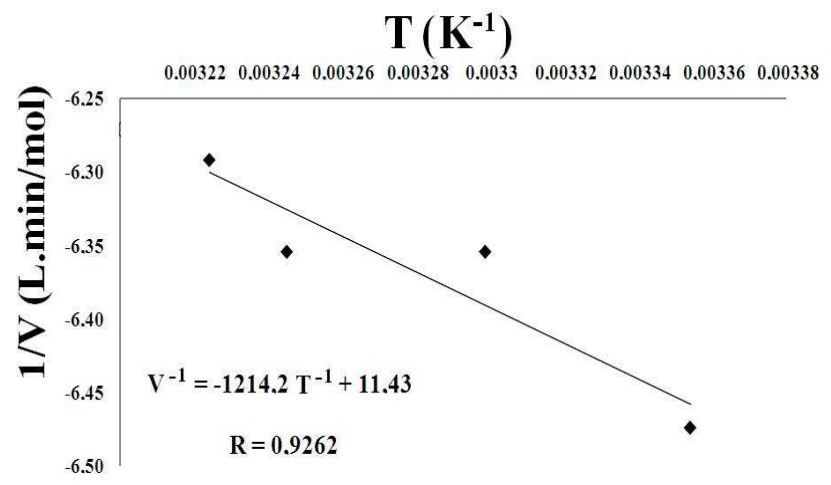

Figure 6 - Determination of activation energy of olive oil hydrolysis reaction by B. cepacia lipase.

\section{pH effects on lipase activity}

$\mathrm{pH}$ effects on olive oil hydrolysis by B. cepacia lipase were examined in the $\mathrm{pH}$ range between 3.0 and 11.0. According to Figure 7, the maximum of relative activity $(100 \%)$ was observed at $\mathrm{pH} 8.0$ (2.38 $\mathrm{U} / \mathrm{mL}$ and specific activity of $25.35 \mathrm{U} / \mathrm{mg}$ ). Also, it was observed that in the range of $\mathrm{pH} 5.0$ and $7.080 \%$ of the maximum activity was maintained. Reasonable activities were obtained even in more acid $\mathrm{pH}$ values, and lower activities in more basic $\mathrm{pH}$ values (9.0 and 10.0). At $\mathrm{pH}$ 11.0, a decrease in the activity was observed. $B$. cepacia lipase appeared as alkaline and analog to $P$. fluorescens lipase studied by Makhzoum et al. (1996). Similar results were found by Sharma et al. (2002) for Bacillus sp at $\mathrm{pH} 8.0$ and 9.0; Bradoo et al. (1999) found optimal values between 3.0 and 6.0 as B. stearothermophilus lipase. P. fluorescens lipases showed maximum activity at
$\mathrm{pH}$ 7.0. These values demonstrated that lipase could perform at different ranges of $\mathrm{pH}$. The $\mathrm{pH}$ effects on enzymes is due to variations in the ionization state of the system components as their values vary. Thus, $\mathrm{pH}$ value is important for the various applications lipase.

Stability of crude enzyme enzymatic activity of $B$. cepacia at different buffers and $\mathrm{pH}$ values of 5.0, 8.0 and 11.0 was also examined. The results are shown in Figure 8. Maximum activity (100\%) was observed at $\mathrm{pH} 8.0$ in phosphate buffer, after a 4hour incubation at $37^{\circ} \mathrm{C}$, while at $\mathrm{pH} 5.0$ the activity was $35 \%$ lower in comparison to the activity at the end of $4 \mathrm{~h}$. At $\mathrm{pH} 11$, activity decreased considerably, although in this alkaline condition and with activity relatively lower, enzyme maintained itself stable along the 4-h incubation. This showed that the enzyme might be applied in different industrial sectors.

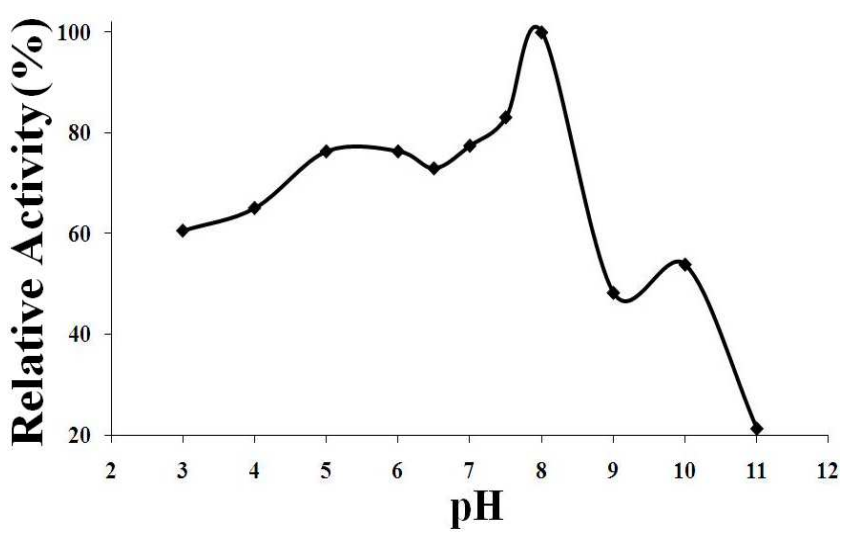

Figure 7 - pH effects on lipolytic activity from B. cepacia. 


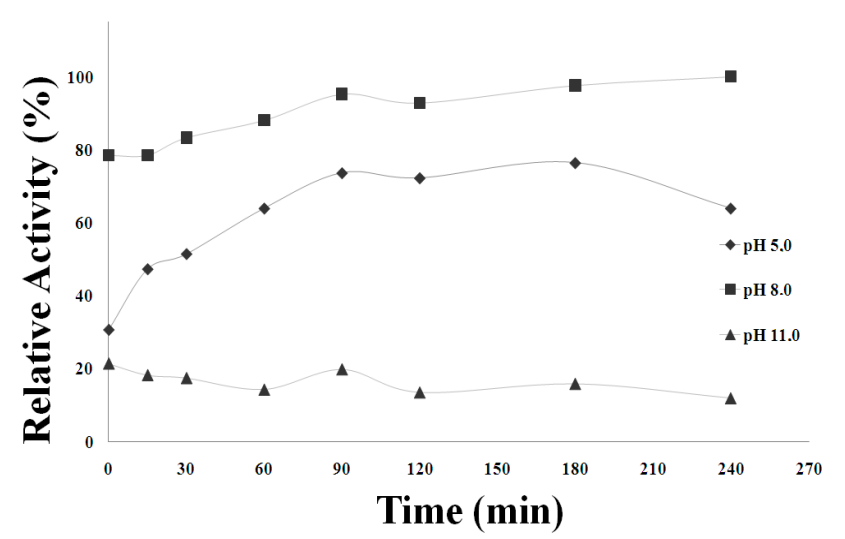

Figure 8 - Effects on pH stability of crude stratum of B. cepacia.

\section{Salt effect on lipase activity}

A study to verify for how many days the crude enzymatic extract would maintain its activity with the addition of different ions was carried out (Fig. 9). To analyze the activity and stability in the different ions, tubes containing a certain quantity of crude enzyme were separated. To each tube, 0.3 $\mathrm{mL}$ of saline solution was added. One of the tubes, containing only crude enzyme, was kept as a control. These tubes were stored in the refrigerators and the analysis of the activity was performed. This study demonstrated that the salts of $\mathrm{Fe}^{2+}$ and $\mathrm{Hg}^{2+}$ significantly decreased the lipolytic activity, leading to a disablement in less than 10 days of storage. On the other hand, the addition of the salts of $\mathrm{Ba}^{2+}, \mathrm{Ca}^{2+}$ and $\mathrm{Mn}^{2+}$ managed the store of enzymatic activity for 30 days, with significant activity decreasing as from the $15^{\text {th }}$ day. These ions still maintained a great percentage of enzymatic activity on the $30^{\text {th }}$ day in comparison to the first day. Salt of $\mathrm{I}^{-}$led to a significant loss of hydrolytic activity in the first days of storage, although after this period, $23 \%$ of enzymatic activity was maintained up to the $30^{\text {th }}$ day. The salts of $\mathrm{Al}^{3+} \mathrm{Co}^{2+}, \mathrm{Cu}^{2+}$ and $\mathrm{K}^{+}$led to a decrease in the lipolytic activity of 75, 40, 45 and $50 \%$ up to the $10^{\text {th }}$ day, respectively. A study using the crude enzyme was also carried out, and a gradual decrease in the activity along the storage was observed, with a decrease in activity of approximately $80 \%$ by the end of the $30^{\text {th }}$ day in comparison to initial storage. Similar studies on $P$. fluorescens lipases were carried out by Makhzoum et al. (1996), in which $\mathrm{Co}^{2+}$ and $\mathrm{Hg}^{2+}$ proved to be strong inhibitors of this enzyme, whereas $\mathrm{Cu}^{2+}$ and $\mathrm{Ba}^{2+}$ led to a moderate inhibition, and $\mathrm{Fe}^{2+}$ did not have any effects on lipases.

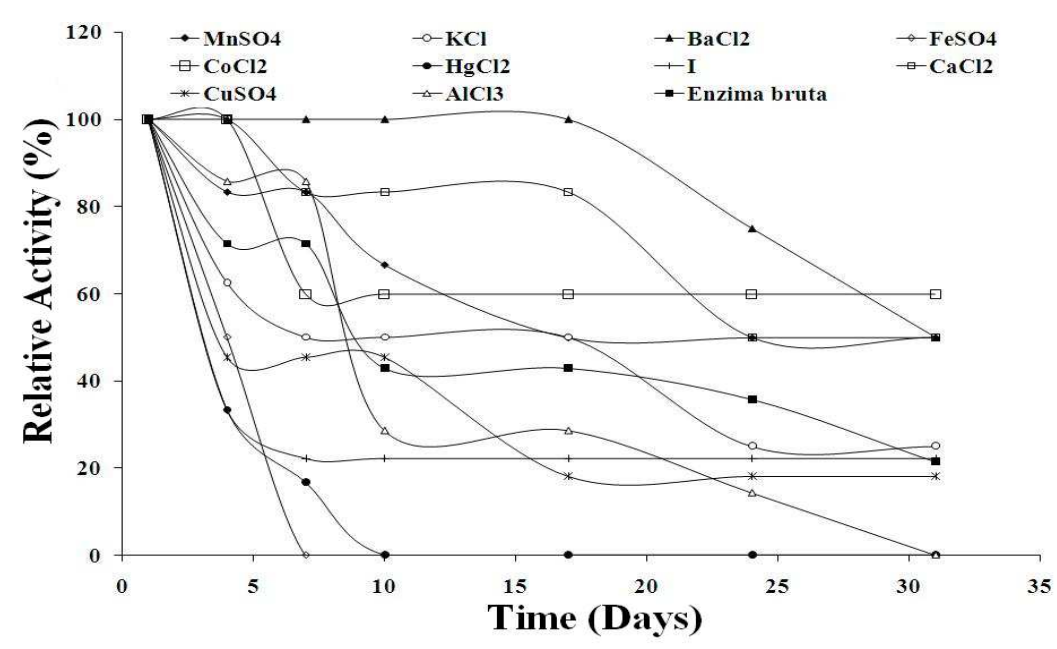

Figure 9 - Ion effects on hydrolytic activity of B. cepacia lipase. 
Lipolytic activity had a considerable activation (a $40 \%$ increase in the activity) by the salt of I. The salts of ions $\mathrm{Mn}^{2+}, \mathrm{Co}^{2+}$ and $\mathrm{Ca}^{2+}$ maintained the enzyme stability along this period and the salts of $\mathrm{Fe}^{2+}, \mathrm{Hg}^{2+}$ and $\mathrm{Al}^{3+}$ performed as inhibitors, leading to a significant enzymatic disablement. The addition of salts to the solution contained Bacillus sp RSJ-1 lipases, studied by Sharma et al. (2002), showed enzyme stability in the presence of $\mathrm{Ba}^{2+}$. On the other hand, ions as $\mathrm{K}^{+1}$ and $\mathrm{Co}^{2+}$ were great inhibitors of lipolytic enzyme. However, $\mathrm{Ca}^{2+}$ maintained the enzyme very active (an increase of $125 \%$ in the activity in comparison to control sample). In the studies carried out by Makhzoum et al. (1996), $\mathrm{Co}^{2+}$ and $\mathrm{Ba}^{2+}$ corroborated these results in $P$. fluorescens lipases, and Lima et al. (2004) found, for $P$. aurantiogriseum lipase, some results which were similar to the ones obtained in this study, where the salts of $\mathrm{Ba}^{+}, \mathrm{Ca}^{2+}, \mathrm{Co}^{2+}, \mathrm{Cu}^{2+}$ and $\mathrm{Hg}^{2+}$ maintained $70,79,105,69$ and $0 \%$ of residual activity, respectively.

\section{Kinetics of olive oil hydrolysis}

Kinetic parameters determination was performed at $37^{\circ} \mathrm{C}$ and $\mathrm{pH}$ 8.0. Data experimentally obtained allowed for the obtainment of kinetic curve, which demonstrated the influence of oil and water emulsion containing different proportions of olive oil $(0.1$ to $50 \% \mathrm{v} / \mathrm{v})$ on the hydrolysis velocity by B. cepacia lipases. It was observed that the activity increased according to the increase in the substrate concentration, (Fig. 10).

As an attempt to describe the kinetic behavior of B. cepacia lipase, data were analyzed based on Michaelis-Menten equation $\left(\mathrm{V}_{0}=\mathrm{V}_{\max } *[\mathrm{~S}] / \mathrm{K}_{\mathrm{M}}+\right.$ $[S])$. This equation is graphically represented by plotting $\mathrm{V}_{0}$ (initial activity) against $\mathrm{S}$ (substrate concentration) and describes a rectangular hyperbola. Figure 11 is the linearization of kinetic data according to Lineweaver-Burk methodology. From the equation, it was possible to determine the values of $K m 0.0258 \mathrm{U} / \mathrm{mg}$ and $V_{\max } 43.90 \mathrm{~g} / \mathrm{L}$.

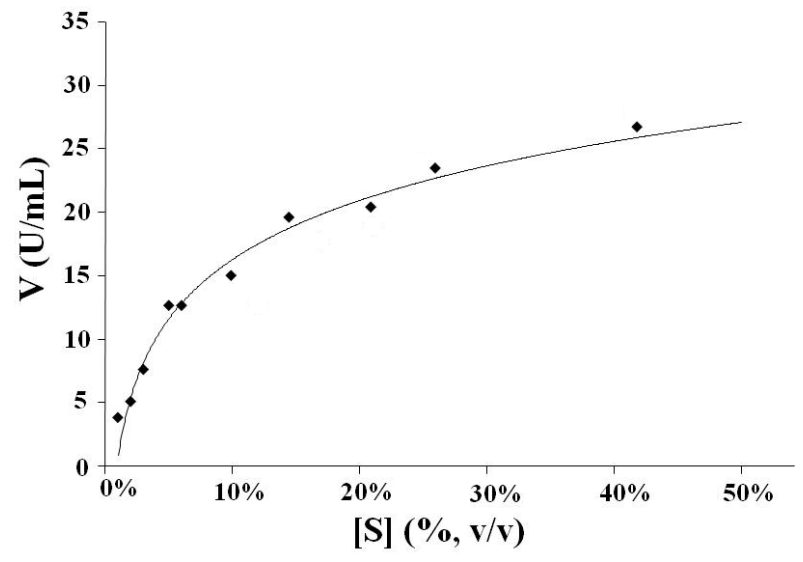

Figure 10 - Kinetic curve of olive oil hydrolysis by B. cepacia lipases.

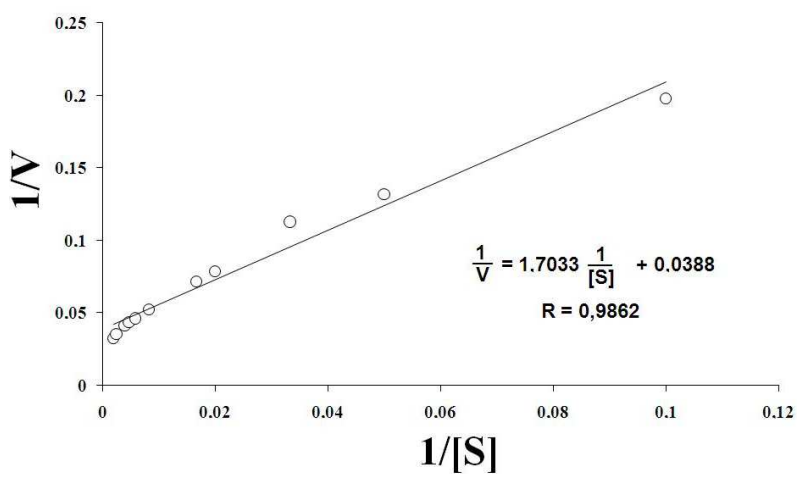

Figure 11 - Lineaweaver-Burk to B. cepacia lipase. 


\section{Molar weight and isoelectrical point}

After the batch ATPS process, the top phase sample of the best system was analyzed by the SDS-PAGE for the determination of enzyme molecular weights and degree of purification. Protein fractions obtained from the purified material by ATPS PEG/phosphate salt at $\mathrm{pH} 6.0$ and from crude enzymatic stratum were analyzed by the electrophoresis by the SDS-PAGE. Figure 12 showed that the extracted enzyme was pure and the molecular weights was $33 \mathrm{kDa}$. It was noted that the purified lipase (band 1) by ATPS/Phosphate (in this work) was more pure than commercial lipase (band 2).

Comparing the obtained values to literature results, $32 \mathrm{kDa}$ was obtained by Lin et al. (1996) for the purified $P$. pseudoalcaligenes lipase F-111 and Baron (2008), who after lipase purification of $B$. cepacia in Octyl Sepharose CL-4B hydrophobic interaction column, also found the molecular weight to be $32 \mathrm{kDa}$. Similar results were obtained by Kordel et al. (1991), where molecular weight obtained for Pseudomonas sp lipase was $35 \mathrm{kDa}$. Lima et al. (2004) found $40 \mathrm{kDa}$ for $B$. megaterium lipase. Lipase molecular weight values from different sources are usually between 19 and $65 \mathrm{kDa}$ (Bandmann et al. 2000), but they can vary from $8 \mathrm{kDa}$ to $180 \mathrm{kDa}$. In this study, molecular weight value demonstrated that ATPS technique to purify $B$. cepacia lipases was efficient in comparison to the fraction before and after purification with commercial B. cepacia lipase.

Figure 13 shows the electrophoresis of isoelectric focusing (IEF) of lipase purified at ATPS pH 6.0. IEF revealed with silver nitrate displayed $\mathrm{pI}$ of 5.0. Kordel et al. (1991) found from 4.5 to $4.6 \mathrm{pI}$ for Pseudonomas sp lipase; pI of 7.3 was found by Lin et al. (1996) for $P$. pseudoalcaligenes lipase; pI results for B. cepacia lipase were not found in the literature up to the present moment.

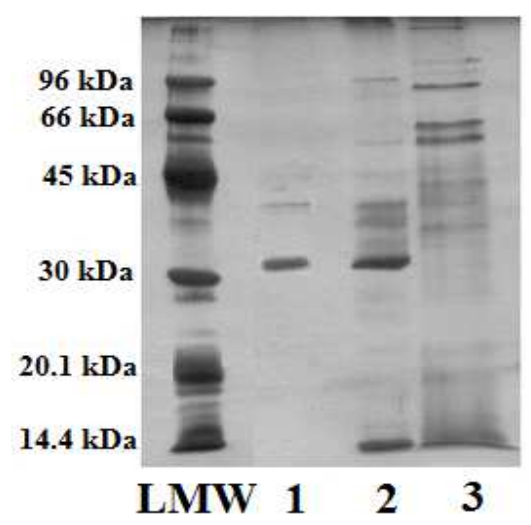

Figure 12 - SDS-PAGE electrophoresis in $12.5 \%$ gel, sample in denaturant and reducing conditions. (LMW) low molecular weight indicator; (1) sample of purified lipase in PEG/phosphate salt aqueous two-phase system at pH 6; (2) commercial lipase of B. cepacia; (3) crude enzymatic stratum.

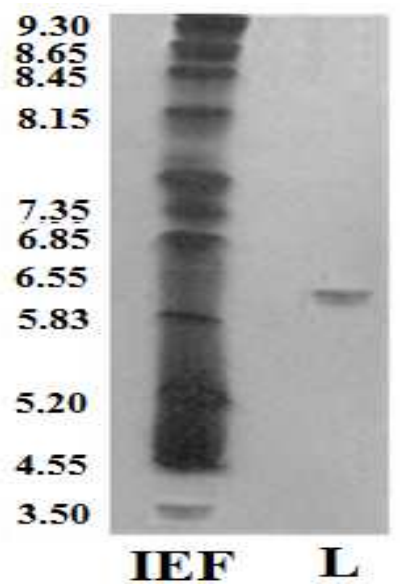

Figure 13 - Electrophoresis of isoelectric focusing at pHs from 3 to 9. (IEF): indicator of isoelectric point; (L): sample of purified lipase in PEG/phosphate salt aqueous two-phase system at $\mathrm{pH} 6$. 


\section{CONCLUSIONS}

The best condition of partitioning of crude stratum from Burkholderia cepacia by PEG/phosphate aqueous two phase system was obtained at $\mathrm{pH} 6.0$ or 8.0 , for which the partitioning coefficient were amongst 108 and 209. Lipase enzyme presented optimal activity conditions at $37^{\circ} \mathrm{C}$ and $\mathrm{pH} 8.0$ and showed pH-stability for $4 \mathrm{~h}$ at $37^{\circ} \mathrm{C}$. The enzyme activity was positively influenced by the $\mathrm{Mn}^{2+}$, $\mathrm{Co}^{2+}, \mathrm{I}^{-}$and $\mathrm{Ca}^{2+}$ and was inhibited by the presence of $\mathrm{Fe}^{2+}, \mathrm{Hg}^{2+}$ and $\mathrm{Al}^{3+}$. Its $\mathrm{K}_{\mathrm{m}}$ and $\mathrm{V}_{\max }$ values were $0.258 \mathrm{U} / \mathrm{mg}$ and $43.90 \mathrm{~g} / \mathrm{L}$, respectively, and the molecular weight and isoelectric point were 33 $\mathrm{kDa}$ and $\mathrm{pH} 5.0$, respectively.

\section{REFERENCES}

Aguilar G, Morlon-Guyot J, Trejo-Aguilar B and Guyot JP. Purification and characterization of and extracellular a-amylase produced by Lactobacillus manihotivorans LMG 18010T, an amylolytic lactic acid bacterium. Enzyme Microb Tech. 2000; 27(6): 406-413.

Albertsson PA. Partition of cell particles and macromolecules. 3nd., New York: John Willey; 1986.

Baron AM. Preparação e caracterização de lipases imobilizadas para utilização em biocatálise [Doctoral thesis in Chemistry], Curitiba, PR, Brazil: Federal University of Paraná; 2008.

Balcão VM, Paiva AL and Malcata FX. Bioreactors with immobilized lipases: State of the art. Enzyme Microb Tech. 1996; 18: 392-416.

Beisson F, Tiss A, Rivière C and Verger R. Methods for lipase detection and assay: a critical review. Eur $J$ Lipid Sci Tech. 2000; 102(2): 133-153.

Bandmann N, Collet E, Leijein J, Uhlén M, Veide A, Nygren PA. Genetic engineering of the Fusarium solani pisi lipase cutinase for enhanced partition in PEG-phosphate aqueous two phase system. $J$ Biotechol. 2000; 79: 161-172.

Biazus JPM, Souza RR, Márquez JE, Franco TT, Santana JCC and Tambourgi EB. Production and characterization of amylases from Zea mays malt. Braz Arch Biol Technol. 2009; 52(5): 991-1000.

Biazus JPM, Santana JCC, Souza RR, Jordão E, Tambourgi EB. Continuous extraction of $\alpha$ - and $\beta$ amylases from Zea mays malt in a PEG $4000 / \mathrm{CaCl}_{2}$ ATPS. J. Chromatogr B. 2007; 858(1-2): 227-233.

Biazus JPM, Severo Jr, JB, Santana JCC, Souza RR, Tambourgi EB. Study of amylases recovery from maize malt by ion-exchange expanded bed chromatography. Process Biochem. 2006; 41(8): 1786-1791.
Borgström B and Brockman H. Lipases, New York, USA: Elsevier; 1984.

Cammarota MC, Teixeira GA and Freire DMG. Enzymatic pre-hydrolysis and anaerobic degradation of wastewaters with high fat content. Biotechnol Lett., 2001; 23: 1591-1595.

Bradford MM. A rapid and sensitive method for the quantitation of microgram quantities of protein utilizing the principle of protein-dye binding. Anal Biochem. 1976; 72: 248-254.

Bradoo S, Saxena RK and Gupta R. Partitioning and resolution of mixture of two lipases from Bacillus stearothermophilus SB-1 in aqueous two-phase system. Process Biochem. 1999; 35(1): 57-62.

Curvelo Santana JC, Araújo SA, Librantz AFH and Tambourgi EB. Optimization of corn malt drying by use of a genetic algorithm. Dry Technol. 2010, 28(11): 1236-1244

Diamond, AD and Hsu JT. Aqueous two phase systems for biomolecule separation. Adv Biochem Eng. 1992; 47: 89-135.

Ferreira GB, Evangelista AF; Severo Jr JB, Souza RR, Santana JCC, Tambourgi EB, et al. Partitioning Optimization of Proteins from Zea mays Malt in ATPS PEG 6000/ $\mathrm{CaCl}_{2}$. Braz, Arch Biol Technol. 2007; 50(3): 557-564.

Ferreira JF, Santana JCC, Tambourgi EB. The Effect of $\mathrm{pH}$ on bromelain partition from Ananas comosus by PEG4000/Phosphate ATPS. Braz Arch Biol Technol. 2011; 54(1): 125-132.

Ferreira JF, Padilha GS, Tambourgi EB. Efeitos da massa molar e do $\mathrm{pH}$ sobre o equilíbrio termodinâmico do sistema bifásico aquoso PEG/fosfatos. Exacta. 2011; 7(1): 49-56.

Fileti AMF, Fischer GA and Tambourgi EB. Neural modeling of bromelain extraction by reversed micelles. Braz Arch Biol Technol. 2010; 53(2): 455463.

Fileti AMF, Fischer GA, Santana JCC and Tambourgi EB. Batch and continuous extraction of bromelain enzyme by reversed micelles. Braz Arch Biol Technol. 2009; 52(5): 1225-1234.

Gautam R, Bassi AS, Yanful K. Candida rugosa lipasecatalyzed polyurethane degradation in aqueous medium. Biotechnol. Lett. 2007, 29(7): 1081-1086.

Hasan F, Shah AA and Hameed A. Industrial applications of microbial lipases. Enzyme Microb Technol. 2006; 39(2): 235-251.

Jaerger KE and Reetz MT. Microbial lipases form versatile tools for biotechnology. Trends Biotechnol. 1998; 16(9): 396-403.

Kamimura ES, Mendieta O, Sato HH, Pastore GM, Maugeri F. Production of lipase from Geotrichum sp. and adsorption studies on affinity resin. Braz J Chem Eng. 1999; 16(2): 103-112. 
Kirk O, Borchert TV and Fuglsang CC. Industrial enzyme applications. Curr Opin Biotechnol. 2002; 13(4): 345-351.

Kojima Y and Shimizu S. A novel lipase from Pseudomonas fluorescens HU380: Gene cloning, overproduction, renaturation-activation, two-step purification, and characterization. J Biosci Bioeng. 2003; 96(1): 242-249.

Kordel M, Hofmann B, Schomburg D and Schmid R. Extracellular lipase of Burkholderia sp Strain ATCC 21808: purification, characterization, crystallization and preliminary X-ray diffraction data. J Bacteriol. 1991; 177: 4836-4841.

Laemmli UK. Cleavage of structural proteins during the assembly of the head bacteriophage T4. Nature. 1970; 227: 680-685.

Lima VMG, Krieger N, Mitchell DA and Fontana JD. Activity and stability of a crude lipase from Penicillium aurantiogriseum ins aqueous media and organic solvents. Biochem Eng J. 2004; 18(1): 65-71.

Lin SF, Chiou CM and Yeh CM. Purification and partial characterization of an alkaline lipase from Pseudomonas pseudoalcaligenes F-11. Appl Environ Micorbiol. 1996; 62(3): 1093-1095.

Macedo GA, Park YK and Pastore GM. Partial purification and characterization of an extracellular lipase from a newly isolated strain of Geotrichum sp. J. Braz Soc Microbiol. 1997; 28: 90-95.

Makhzoum A, Apenten RKO and Knapp JS. Purification and properties of lipase from Pseudomonas fluorescens strain 2D. New York, USA: Elsevier; 1996. 459-472.

Morrissey JH. Silver stain for proteins in polyacrylamide gels: A modified procedure with enhanced uniform sensitivity. Anal Biochem. 1981; 117: 307-310.

Nawani N, Singh R and Kaur J. Immobilization and stability studies of a lipase from thermophilic Bacillus sp: The effect of process parameters on immobilization of enzyme. Electron J Biotechnol. 2006; 9: 559-565.

Padilha GS, Castiglioni GL, Monte Alegre R, Tambourgi EB. Avaliação de diferentes íons na atividade da lipase de Pseudomonas cepacia. Exacta, 2009a; 7(2): 181-186.

Padilha GS, Santana JCC, Monte Alegre R, Tambourgi EB. Expanded bed adsorption of an alkaline lipase from Pseudomona cepacia. J Chromatogr B. 2009b; 877(5-6): 521-526.
Padilha GS, Ferreira JF, Monte Alegre R, Tambourgi EB. Efeitos do pH e massa molar do polímero sobre o sistema bifásico aquoso PEG/fosfato. Acta Sci Tech. 2011; 33(1): 1-4.

Paiva AL, Balcão VM and Malcata FX. Kinetics and mechanics of reactions catalysed by immobilized lipases. Enzyme Microb Tech. 2000; 27(3-5): 187204.

Pandey A, Benjamin S, Soccol CR, Nigam P, Krieger N and Socool VT. The realm of microbial lipases in biotechnology. Biotechnol Appl Biochem. 1999; 29: $119-131$.

Pastore GM, Costa VSR, Koblitz MGB. Purificação parcial e caracterização bioquímica de lipase extracelular produzida por nova linhagem de Rhizopus sp. Cienc Tecnol Aliment. 2003; 23(2): 135140.

Pencreac'h G and Barrati JC. Hydrolysis of pnitrophenyl palmitate in n-heptane by the Pseudomonas cepacia lipase: a simple test for the determination of lipase activity in organic media. Enzyme Microb Tech. 1999; 18: 417-422.

Ranganathan SV, Narasimhan SL, Muthukumar K. An overview of enzymatic production of biodiesel. Bioresour Technol., 2008; 99(10): 3975-3981.

Saxena RK, Sheoran A, Giri B, Davidson WS. Purification strategies for microbial lipases. $J$ Microbiol Meth. 2003; 52(1): 1-18.

Sharma R, Soni SK, Vohra RM, Gupta LK and Gupta JK. Purification and characterisation of a thermostable alkaline lipase from a thermophilkic Bacillus sp. RSJ-1. Process Biochem. 2002; 37(10): 1075-1084.

Silva ME and Franco TT. Liquid-liquid extraction of biomolecules in downstream processing - A review paper. Braz J Chem Eng. 2000; 17(1): 1-17.

Singh S and Banerjee U.C. Interactions of proteins with immobilized metal ions. Process Biochem. 2007; 42(7): 1063-1068.

Toledo AL, Severo Jr, JB, Souza RR, Campos ES, Santana JCC, Tambourgi EB. Purification by expanded bed adsorption and characterization of an $\alpha$-amylases FORILASE NTL® from A. niger. $J$ Chromatogr B. 2007; 846(1-2): 51-56.

Wanderley KJ, Torres FAG, Moraes LMP, Ulhoa CJ. Biochemical characterization of $\alpha$-amylase from the yeast Cryptococcus flavus. FEMS Microbial Lett. 2004; 231(2): 165-169. 


\section{PÁGINA EM}

BRANCO 